\title{
Biomimetic and Bioinspired Crystallization with Macromolecular Additives
}

\author{
Il Won Kim \\ Department of Chemical Engineering, Soongsil University, Seoul, \\ South Korea
}

\section{Introduction}

Biominerals in nature have intrigued scientists and engineers alike because of their unusual structures and properties, and the biomineral examples of extraordinary properties are continually growing with further research efforts. Therefore, biomineralization has become one of the more promising inspirations for the new paradigm of the crystallization science and technology.

The controls found in the biomineralization have been investigated in detail to understand the mechanism, or at least the tools, of forming the intricate structures of the biominerals. The structural controls have been found in the hierarchical levels of the materials. Molecular packing is regulated to generate specific polymorphs of the crystals. Nano- and microdomains are organized to form the bulk crystals that have unusual shapes and orientations. One of the well-known examples can be found in the abalone nacre. The metastable aragonite is the main constituent of the nacre, while calcite is the thermodynamically stable phase. [Belcher et al., 1996] Also, the nacre has layered structures of micro-plates, which in turn are the assemblies of nano-domains. [Li et al., 2004]

The exact mechanisms to steer the mineralization pathways to form such intricately arranged structures are still under various investigations to be fully unraveled. However, it is now well known that the biomacromolecules that possess the specific interactions with the mineral phases are of utmost importance in the mineralization controls.

This chapter discusses calcium-based biominerals to review the role of biomacromolecules in the mineralization. Biominerals based on calcium carbonate and calcium oxalate are the subject materials to explore. Also, some biomimetic approaches that partly replicate the biomineralization processes are discussed.

Biomimetic crystallization can be defined as the process that mimics the desired aspects observed in biomineralization. When the biomacromolecules implicated in the biomineralization have been directly used, identifying their roles in the mineral formation has been of the initial interests. Also, some fragments of the biomacromolecules have been investigated in vitro for the similar purpose. In addition, synthetic polymers and peptides have been applied to the crystallization that mimicked the special controls of the biomineralization.

\section{Case studies of the biomineralization of calcium carbonate}

Proteins implicated in the formation of mollusk shells (calcium carbonate) have been actively studied in their structures and functions. While the related publications have 
increased in their numbers, by examining diverse biological species, some of the early examples are represented by the studies of Pacific red abalone (Haliotis rufescens) and Japanese pearl oyster (Pinctada fucata). In both cases, the focus of many studies was on the formation of nacreous layers. The nacreous layers have aragonite, a metastable phase of calcium carbonate, as the inorganic constituent, and its formation mechanism over calcite, the stable phase of calcium carbonate under ambient conditions, has been investigated in terms of the selective control by biomacromolecules.

\subsection{Biomacromolecules associated with Haliotis rufescens}

AP7, AP8, and AP24 are the proteins identified from the abalone nacre (H. rufescens), and the names indicate the molecular weight $(7,8$, and $24 \mathrm{kDa})$ of the aragonitic proteins (AP). AP7 and AP24 were isolated as EDTA-soluble proteins, and they appeared to form a complex through strong intermolecular interactions. [Michenfelder et al., 2003] AP8, on the other hand, was obtained as the soluble component in aqueous solutions of both acetic acid and ammonium sulfate. [Fu et al., 2005a] The compositions of these proteins suggested that the acidic amino acids were the vital part of the protein structures to interact with the calcium carbonate. The acidic amino acids appear beneficial in the protein interactions with calcium ions as well as the mineral surfaces of calcium carbonate.

\begin{tabular}{|c|c|}
\hline Protein & Amino acid sequence or composition \\
\hline AP7 & $\begin{array}{l}\text { DDNGNYGNGM ASVRTQGNTY DDLASLISYL TRHSFRRPFH ECALCYSITD } \\
\text { PGERQRCIDM YCSYTN }\end{array}$ \\
\hline AP8- $\alpha$ & $\begin{array}{l}\text { Asx } 36.5 \% \text {, Thr } 1.2 \% \text {, Ser } 4.7 \% \text {, Glx 5.2\%, Pro } 2.1 \% \text {, Gly } 37.7 \% \text {, Ala } 5.2 \% \text {, Try } \\
0.4 \% \text {, Phe } 1.2 \% \text {, Lys } 2.8 \% \text {, Arg } 3.0 \%\end{array}$ \\
\hline AP8- $\beta$ & $\begin{array}{l}\text { Asx 34.5\%, Thr 0.6\%, Ser 2.8\%, Glx 8.4\%, Pro } 1.9 \% \text {, Gly 39.6\%, Ala 3.0\%, Lys } \\
4.7 \%, \text { Arg } 4.3 \%\end{array}$ \\
\hline AP24 & $\begin{array}{l}\text { ADDDEDASSG LCNQYNQNVT TRPNNKPKMF LRKNINFEII } \\
\text { SVHNIWRDPN TVYWCDFSLE EEDGIKHWRH YDFNATHWWV } \\
\text { EKGCSGTFVV EECNTKDITN PGPRSTAGKS PMQGTLAAPK } \\
\text { PVANWMSIMS RSRFDMGTWD KEGFNML }\end{array}$ \\
\hline
\end{tabular}

Note that one-letter and three-letter codes were used for amino acid sequences and compositions, respectively. Also, Asx $=$ Asp or Asn, and Glx $=$ Glu or Gln.

Table 1. Amino acid sequences of AP7, AP8, and AP24 proteins.

The secondary structure of AP7 (66 amino acids), among the AP proteins, was most thoroughly studied. [Collino et al., 2008; Kim et al., 2004a, 2006a; Wustman et al., 2004] Its $\mathrm{N}$-terminal domain (AP7N, 30 amino acids) was structurally labile, while its C-terminal sequence (AP7C, 36 amino acids) possessed short a-helical regions. It was interesting that the in vitro crystallization revealed that the AP7 and AP7N demonstrated similar effects on the growth of calcium carbonate, while the AP7C did not display visible effects. The initial result on the secondary structures of AP8 similarly indicated combinations of unfolded and structured regions, while the local distributions of the various structures were not well defined. [Fu et al., 2005b] The N-terminal domain of AP24 also showed an unfolded structure comparable to AP7N, and their effects on the growth of calcium carbonate crystals were of the same nature. [Michenfelder et al., 2003; Wustman et al., 2004] These results indicate the importance of the labile structures in the intrinsically disordered proteins (IDP) that modulate the biomineralization of the abalone nacre. 
In situ atomic force microscopy (AFM) has been one of the important tools to observe the in vitro biomimetic crystallization of calcium carbonate. For example, in situ AFM studies were performed for AP7N, AP8, and AP24N. [Fu et al., 2005b; Kim et al, 2006b] These studies revealed the surprising effects of growth acceleration that had not been observed before, and the underlying mechanism appeared to be through lowering the activation barriers for moving ions from the solution phase to the crystal growth sites [Elhadj et al., 2006; Kim et al, 2006b]. These results indicate the ability of the biomacromolecules to modulate the mineral/solution interfaces to control the kinetics of crystallization.

\begin{tabular}{|l|l|}
\hline Peptide & \multicolumn{1}{c|}{ Amino acid sequence } \\
\hline AP7N & DDNGNYGNGM ASVRTQGNTY DDLASLISYL \\
\hline AP7C & TRHSFRRPFH ECALCYSITD PGERQRCIDM YCSYTN \\
\hline AP24N & ADDDEDASSG LCNQYNQNVT TRPNNKPKMF \\
\hline
\end{tabular}

Note that one-letter codes were used for amino acid sequences.

Table 2. Amino acid sequences of AP7N, AP7C, and AP24N peptides.

Biomimetic crystallization to reproduce the nacre formation of $H$. rufescens was initially performed using the mixture of anionic proteins isolated from the aragonitic layer. The anionic proteins prompted the aragonite formation, irrespective of the presence or absence of the nucleating protein sheets also obtained from $H$. rufescens, which indicated that these proteins were the key components in the polymorphic control of the biomineralization. [Belcher et al., 1996] Recent study showed that the AP7 protein was able to form metastable aragonite as well as amorphous calcium carbonate. [Amos and Evans, 2009] It is noteworthy that AP7 also has a function of limiting the growth of calcite, which is the most stable polymorph of calcium carbonate, because suppressing the calcite formation should be helpful, if not required, to produce the metastable phases.

Lustrin A, a matrix protein of $H$. rufescens is also worth mentioning, although it does not appear directly related to the controlled biomineralization. It was identified as a protein (116 kDa, 1,428 amino acids) localized to the regions between aragonite layers in the nacre, and it contained alternating cysteine-rich and proline-rich domains. [Shen et al., 1997; Wustman et al., 2003a] The freshly cleaved nacre exhibited sawtooth-shaped forceextension curves during tensile pulling experiments using an atomic force microscope, and the Lustrin A protein is believed to act as a biomacromolecular adhesive to display the observed behavior and ultimately enhance the toughness of the nacreous layers of $H$. rufescens. [Smith et al., 1999] The study of some part of the cysteine-rich domains revealed a loop conformation that could be a critical factor in the elastomeric behavior of the Lustrin A. [Zhang et al., 2002] Interestingly, Lustrin A also possessed an acidic domain (D4) rich in aspartic acid with an unfolded structure that could act as the mineral binding region - another important aspect for its role as a biomacromolecular adhesive. [Wustman et al., 2003a, 2003b] Readers should note that the biomacromolecular adhesive is only one of several reasons responsible for the high toughness of the nacre. Nacre has lamellar architecture constructed with aragonite microplatelets, which in turn are made of polygonal nanograins, and the micro- and nano-structures are both important for its exceptional mechanical properties. [Li et al., 2004, 2006] 


\begin{tabular}{|l|l|}
\hline $\begin{array}{l}\text { Protein } \\
\text { or } \\
\text { peptide }\end{array}$ & \multicolumn{1}{|c|}{ Amino acid sequence or composition } \\
\hline Lustrin A & $\begin{array}{l}\text { Ser 16.39\%, Pro 13.87\%, Gly 13.38\%, Gys 9.17\%, Val 6.23\%, Ala 5.95\%, } \\
\text { Thr 5.32\%, Arg 4.90\%, Leu 4.41\%, Gln 3.92\%, Asp 3.85\%, Lys 2.24\%, Glu 2.10\%, } \\
\text { Ile 2.03\%, Tyr 1.96\%, Phe 1.68\%, Asn 1.26\%, Trp 0.84\%, His 0.35\%, Met } 0.14 \%\end{array}$ \\
\hline RKSY & YRGPIARPRS SRYLAKYLKQ GRSGKRLQKP \\
\hline D4 & GKGASYDTDA DSGSCNRSPG YLPG \\
\hline
\end{tabular}

Note that one-letter and three-letter codes were used for amino acid sequences and compositions, respectively.

Table 3. Amino acid composition and sequences of Lustrin A and its related peptides [Shen et al., 1997; Wustman et al., 2003a].

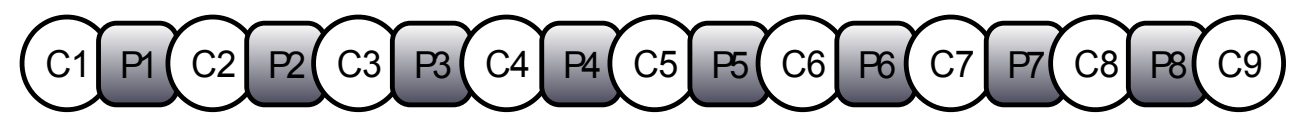

Fig. 1. Schematic of the N-terminal regions of Lustrin A that shows the alternating cysteinerich and proline-rich domains; redrawn after Shen et al. (1997). C1 to C9 indicate cysteinerich domains, and P1 to P8 specify proline-rich regions.

\subsection{Biomacromolecules associated with Pinctada fucata}

N16 $(16 \mathrm{kDa})$ family and nacrein are the proteins originally identified from the nacreous shell layer and the pearl of the oyster ( $P$. fucata). The N16 was a family of proteins associated with EDTA insoluble organic matrix, and it was separated by using a dilute alkali solution. It was also hydrophilic and acidic in its composition, and it showed an ability to regulate the crystallization of calcium carbonate in vitro. [Samata et al., 1999] The N- and C-terminal sequences of $\mathrm{N} 16$ (N16N and N16C, both 30 amino acids) were analyzed in their structural changes along with concentrations, $\mathrm{pH}$, and the presence of calcium ions. [Amos et al. 2011; Kim et al., 2004b] They had a mixture of unfolded and $\beta$-stranded structures, and they appeared to form supramolecular assemblies regulated by $\mathrm{pH}$ and calcium ions. This is consistent with the preliminary analysis of the secondary structure of N16 and with the fact that N16 is a matrix protein. [Samata et al., 1999] Also found in the pearl oyster (P. fucata) was nacrein $(60 \mathrm{kDa})$. It was isolated as the EDTA-soluble protein, and it appeared to have domains that regulated both calcium and carbonate components of the biomineral. The calcium-interacting domain had repeating structures of Gly-Xaa-Asn where Xaa was mainly Asp or Asn, and the carbonate-regulating regions showed homology with carbonic anhydrase. [Miyamoto et al., 1996] Especially, the carbonic anhydrase-like domains could play a critical role in conversion of $\mathrm{CO}_{2}$ to $\mathrm{HCO}_{3}^{-}$, ultimately supplying the $\mathrm{CO}_{3}{ }^{2-}$ constituent of the calcium carbonate minerals. Nacrein was originally identified from the nacreous layer of $P$. fucata, but it now appeared responsible for the shell formation in general. [Takeuchi and Endo, 2006] The hypothesis of the general usage seems more plausible with the finding that the homologous proteins have been discovered in other related species. [Kono et al., 2000; Norizuki and Samata, 2008] Note that when oligosaccharides were found as linked to nacrein, alternative explanation for the $\mathrm{Ca}^{2+}$ uptake was suggested - the negatively charged sulfite and sialic acid in the N-glycan. [Takakura et 
al., 2008] More recently, an acidic matrix protein, termed Pif, was identified from the acidinsoluble material of $P$. fucata; it was an aragonite-specific protein found by a calcium carbonate binding assay. It is believed to have domains that can bind chitin and aragonite, and it appears to form protein complex with N16 to regulate the oriented aragonite formation in the nacreous layer. [Suzuki et al., 2009]

\begin{tabular}{|l|l|}
\hline $\begin{array}{l}\text { Protein } \\
\text { or } \\
\text { peptide }\end{array}$ & \multicolumn{1}{c|}{ Amino acid sequence } \\
\hline N16-1 & $\begin{array}{l}\text { AYHKKCGRYS YCWIPYDIER DRYDNGDKKC CFCRYAWSPW } \\
\text { QCNEEERYEW LRCGMRFYSL CCYTDDDNGN GNGNGNGNGL } \\
\text { NYLKSLYGGY GNGNGEFWEE YIDERYDN }\end{array}$ \\
\hline N16N & AYHKKCGRYS YCWIPYDIER DRYDNGDKKC \\
\hline N16C & GLNYLKSLYG GYGNGNGEFW EEYIDERYDN \\
\hline
\end{tabular}

Note that one-letter codes were used for amino acid sequences. Also, N16-1 was the representative protein among N16 family.

Table 4. Amino acid sequence of N16 and its related peptides [Samata et al., 1999; Kim et al., 2004b].

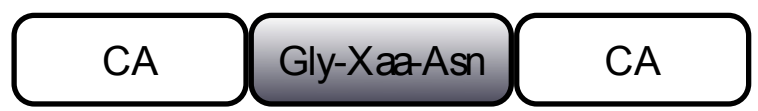

Fig. 2. Schematic of the nacrein protein sequence; redrawn after Miyamoto et al. (1996). CA indicates domains homologous to carbonic anhydrase, and Xaa in Gly-Xaa-Asn is mainly Asp or Asn.

\begin{tabular}{|c|c|}
\hline $\begin{array}{l}\text { Protein/ } \\
\text { Sequence }\end{array}$ & Amino acid sequence \\
\hline $\begin{array}{l}\text { Nacrein/ } \\
61-109\end{array}$ & GPHYWHTISK CF-IACGICQ RQSPINIVSY DAKFRQRLPK LKFKPHMEKL \\
\hline $\begin{array}{l}\text { CA/ } \\
11-52\end{array}$ & GPEHWH---K DFPIA--KGE RQSPVDIDTH TAK---YDPS LKPLSVSYDQ \\
\hline $\begin{array}{l}\text { Nacrein/ } \\
379-416\end{array}$ & YYTYEGSLTT PPCTESVLWV VQKCHVQV-S RRVL-HALRN \\
\hline $\begin{array}{l}\text { CA/ } \\
189-218\end{array}$ & YWTYPGSLTT PPLLECVTWI VLKEPISVSS EQVLKFRKLN \\
\hline
\end{tabular}

Note that one-letter codes were used for amino acid sequences.

Table 5. Some amino acid sequences of nacrein and carbonic anhydrase (CA) that show the homology between the proteins [Miyamoto et al., 1996].

Biomimetic crystallization to reproduce the nacre formation of $P$. fucata has been performed in the context of using the combinations of $\beta$-chitin, silk fibroin-like proteins, and acidic proteins to reconstruct the biological mineralization environments. [Falini et al., 1996] N16N showed binding affinity to $\beta$-chitin (but not to $\alpha$-chitin), and induced aragonite formation 
(occurrence rate, 89\%). [Keene et al., 2010a] Note that N16N alone could induce aragonite growth, but the occurrence rate was much lower (27\%). [Metzler et al., 2010] When silk fibroin hydrogels were introduced to the N16N- $\beta$-chitin complex, vaterite and amorphous calcium carbonate were obtained. [Keene et al., 2010b] Probably, the most compelling work in the mineralization mimicking the nacre formation of $P$. fucata was done with Pif protein. When Pif-N16 protein complex was added on the chitin-coated glass, highly oriented aragonite formed between chitin and glass. [Suzuki et al., 2009]

The proteins implicated in the crystallization of mollusk shells have been studied with a basic assumption of heterogeneous nucleation of inorganic phases on the organic frameworks. [Weiner and Addadi, 1997] One of the alternative, if not incompatible, hypotheses to this extracellular mechanism is the intracellular nucleation of the nascent crystals. [Mount et al, 2004] Accordingly, the mantle tissue of P. fucata was analyzed to find the genes involved in the control of the mineralization processes as opposed to those encoding the mineral-implicated proteins [Liu et al., 2007]. The highly expressed P. fucata mantle gene was found and designated as PFMG1. Its protein sequence showed homology with a known calcium-binding protein CBP-1 with two EF-hand regions, and, therefore, it was presumed to be involved in the signal transduction during nacre formation as well as the crystal nucleation. [Liu et al., 2007; Skelton et al., 1994] The secondary structure of the PFMG1 was studied for the terminal domains, and they possessed the so-called intrinsically disordered protein sequences (IDP) similar to AP7 and N16. [Amos et al., 2010] It is interesting that the terminal fragment peptides were able to generate aragonite, although the occurrence was not exclusive probably due to the lack of other components that usually participate in the biomineral generation. Clearly, much more multidisciplinary work is expected to be done until we fully understand the principles of mineralization in the biological species.

\begin{tabular}{|l|l|}
\hline $\begin{array}{l}\text { Protein or } \\
\text { peptide }\end{array}$ & \multicolumn{1}{c|}{ Amino acid sequence } \\
\hline PFMG1 & $\begin{array}{l}\text { MRFLTIIATV LVLGVVVCDA RKRWWRRATK KVELKPEIGR } \\
\text { GGDWKVSGGI SISWRKKRSI EKQGKFNIEL TLNPCDLMSY } \\
\text { DSNKDGVVTH EDIKHIFDNE KLAEVFFSEA DENDDEQIST } \\
\text { SEFKDFKSRI NQCVKD }\end{array}$ \\
\hline PFMG1-N & RKRWWRRATK KVELKPEIGR GGDWKVSGGI \\
\hline PFMG1-C & FSEADENDDE QISTSEFKDF KSRINQCVKD \\
\hline
\end{tabular}

Note that one-letter codes were used for amino acid sequences.

Table 6. Amino acid sequence of PFMG1 and its related peptides [Liu et al., 2007; Amos et al., 2010].

\subsection{Amorphous calcium carbonate}

Amorphous phase has been found in some organisms as another form of calcium carbonate. [Lowenstam and Weiner, 1989] It is considered as the temporary storage of calcium and carbonate, and its usage as the structural component has been also discovered. [Aizenberg et al., 1996, 2002; Lowenstam and Weiner, 1989] The representative findings of using the amorphous calcium carbonate (ACC) as the skeletal building blocks were from the calcareous sponge Clathrina and the ascidian Pyura pachydermatina. [Aizenberg et al., 1996, 
2002] The spicule of Clathrina was found to have layered structures of a thin calcitic sheath/a thick ACC/a core of calcite, and the presence of ACC was assumed to provide isotropic and less brittle characteristics that could not be achieved by crystalline calcite. [Aizenberg et al., 1996] It was also found that the proteins, implicated in biogenic ACC and calcite, were able to form stable ACC and calcite in vitro, respectively. Interestingly, the amino acid compositions of the proteins showed subtle differences between each other. ACC-associated proteins were rich in Glx (Glu or Gln), Ser, and Gly, and calcite-implicated proteins were rich in Asx (Asp or Asn). Other notable features of the ACC-associated biomacromolecules were the presence of polysaccharides, which were absent in the calcite proteins, and their ability to inhibit crystallization of calcium carbonate in vitro at an appropriate concentration range. [Aizenberg et al., 1996]

\begin{tabular}{|l|l|}
\hline Spicule part & \multicolumn{1}{|c|}{ Amino acid composition } \\
\hline \multirow{2}{*}{$\begin{array}{l}\text { Amorphous } \\
\text { layer }\end{array}$} & $\begin{array}{l}\text { Asx 7.2\%, Thr 4.3\%, Ser 19.2\%, Glx 17.7\%, Pro 5.4\%, Gly 19.9\%, Ala 8.4\%, } \\
\text { Val 3.5\%, Ile 1.7\%, Leu 2.3\%, Tyr 0.8\%, Phe 1.0\%, Lys 4.1\%, His 3.2\%, } \\
\text { Arg 1.1\% }\end{array}$ \\
\hline Calcite core & $\begin{array}{l}\text { Asx 28.5\%, Thr 3.5\%, Ser 8.8\%, Glx 14.3\%, Pro 4.2\%, Gly 10.8\%, Ala 10.5\%, } \\
\text { Cys 0.2\%, Val 3.5\%, Met 2.1\%, Ile 2.0\%, Leu 2.9\%, Tyr 1.6\%, Phe 2.3\%, Lys } \\
1.7 \%, \text { His 1.1\%, Arg 2.0\% }\end{array}$ \\
\hline
\end{tabular}

Note that three-letter codes were used for amino acid compositions.

Table 7. Amino acid composition of proteins from Clathrina spicule [Aizenberg et al., 1996].

Similar finding was noted for the tunic spicules of the Pyura pachydermatina. [Aizenberg et al., 2002] Also noticeable in this study was the role of the Mg ions, which facilitated the ACC stabilization. This was initially presumed based on the larger $\mathrm{Mg}$ content in the ACC region (5.9\%) than in the calcitic layer (1.7\%). (Note that the Mg content of the ACC and calcite parts of the sponge Clathrina was $11.2 \%$ and $6.4 \%$, respectively.) In vitro experiments also confirmed that the presence of $\mathrm{Mg}$ ions could reduce the critical amount of the ACC proteins required for the ACC stabilization. Analysis of the amino acid compositions of the phase-specific proteins from the Pyura pachydermatina showed a similar trend to that for Clathrina: a high content of Glx (Glu or Gln) for ACC and Asx (Asp or Asn) for calcite. [Aizenberg et al., 2002] Also note that a negatively charged glycoprotein involved in ACC formation was more recently identified from the crayfish Cherax quadricarinatus among crustaceans. [Shechter et al., 2008]

\begin{tabular}{|l|l|}
\hline Spicule part & \multicolumn{1}{|c|}{ Amino acid composition } \\
\hline $\begin{array}{l}\text { Amorphous } \\
\text { region }\end{array}$ & $\begin{array}{l}\text { Asx 7.1\%, Glx 17.2\%, Ser 11.2\%, Thr 12.2\%, Gly 12.6\%, Ala 5.5\%, Val 6.0\%, } \\
\text { Leu 5.3\%, Ile 3.0\%, Arg 8.9\%, Lys 4.4\%, Phe 3.3\%, Tyr 0.4\%, Cys 1.6\%, Pro } \\
1.2 \%\end{array}$ \\
\hline $\begin{array}{l}\text { Calcite } \\
\text { region }\end{array}$ & $\begin{array}{l}\text { Asx 18.8\%, Glx 8.0\%, Ser 6.8\%, Thr 4.6\%, Gly 20.8\%, Ala 6.5\%, Val 4.6\%, } \\
\text { Leu 7.1\%, Ile 1.2\%, Arg 3.4\%, Lys 4.0\%, His 0.8\%, Phe 1.2\%, Tyr 2.2\%, Cys } \\
7.8 \%, \text { Met 1.2\%, Pro 1.0\% }\end{array}$ \\
\hline
\end{tabular}

Note that three-letter codes were used for amino acid compositions.

Table 8. Amino acid composition of proteins from the spicule of Pyura pachydermatina [Aizenberg et al., 2002]. 
Biogenic ACC has been also found as a precursor to eventually form crystalline calcium carbonate. The larval shell of Mercenaria mercenaria showed ACC-to-aragonite transformation in vivo. [Weiss et al., 2002] The biomacromolecules extracted from the Atrina rigida demonstrated ACC-to-aragonite transition when applied in vitro along with $\beta$-chitin and silk scaffold. [Gotliv et al., 2003] Later Asp-rich protein family was identified from the prismatic layer of Atrina rigida, and named Asprich. [Gotliv et al., 2005] This protein appeared to induce ACC formation and inhibit crystallization of calcium carbonate to slowly fine-tune the growth of the prismatic layer. [Politi et al., 2007] It is interesting to note that this protein, that stabilizes ACC only transiently, is rich in Asp, while those found in longer stabilized ACC is rich in Glu (or Gln). Also, the transient ACC and stable ACC appeared different structurally (short range order) and compositionally (water molecules). [Raz et al., 2003] It would be interesting future work to clearly identify the correlations between the structures of the involved proteins and the the formation of ACC in different nature.

\subsection{Additives to regulate the crystallization of calcium carbonate}

Macromolecules, not specifically associated with calcium carbonate biominerals, have been investigated to explore their ability to interact with the inorganic phase and alter its crystallization pathways. Diverse synthetic and biological polymers have been studied to control the size, shape, and polymorphism of calcium carbonate. As in the previous sections dealing with biomineralization, only some representative examples of bioinspired crystallization are introduced in this section. Readers interested in more extensive examples may find the special issue (volume 108, issue 11; November 2008) of Chemical Review useful.
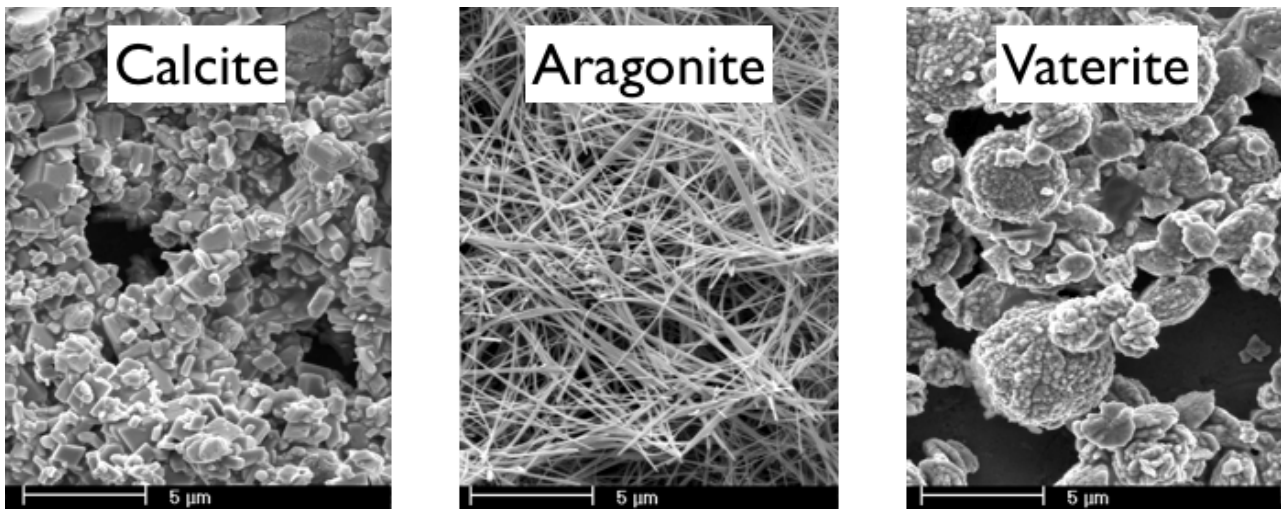

Fig. 3. SEM micrographs showing representative morphology of calcite, aragonite, and vaterite obtained with poly(vinyl alcohol). [Kim et al., 2005]

Poly(vinyl alcohol) was one of the simplest example that showed successful control in the crystallization of calcium carbonate. [Hosoda et al., 2003; Kim et al., 2005; Lakshminarayanan et al., 2003] Poly(vinyl alcohol) was able to adsorb extensively on calcium carbonate to inhibit its crystallization. The inhibition of the crystallization was effective in the order: calcite $>$ aragonite $>$ vaterite. Therefore, the polymorph of calcium carbonate obtained with poly(vinyl alcohol) could be adjusted by changing the amount of poly(vinyl alcohol) in the supersaturated solution. As the concentration of poly(vinyl 
alcohol) increased, (i) the size of the calcite decreased, (ii) calcite was inhibited to form aragonite almost exclusively, and (iii) both calcite and aragonite were inhibited to form vaterite. [Kim et al., 2005] A recent study using in situ atomic force microscopy on a single crystal of calcite also verified the inhibitory effects of poly(vinyl alcohol) to modulate the overgrowth of the calcite. [Kim et al., 2009]

Some biomacromolecules, not originally associated with biominerals, were also able to selectively crystallize aragonite. Bovine serum albumin $(66 \mathrm{kDa})$ appeared to form aggregates via self-assembly that stabilized aragonite polymorph. Note that the critical concentration of the protein required for aragonite polymorph was much higher than that for aragonitic shell proteins. [Amos et al., 2010] Similar behavior was also seen with soy globulins, but it was unclear if the proteins were solely responsible for this result because the aragonite was prepared at slightly elevated temperature $\left(50^{\circ} \mathrm{C}\right)$ that could induce some aragonite formation. [Liu et al., 2009]
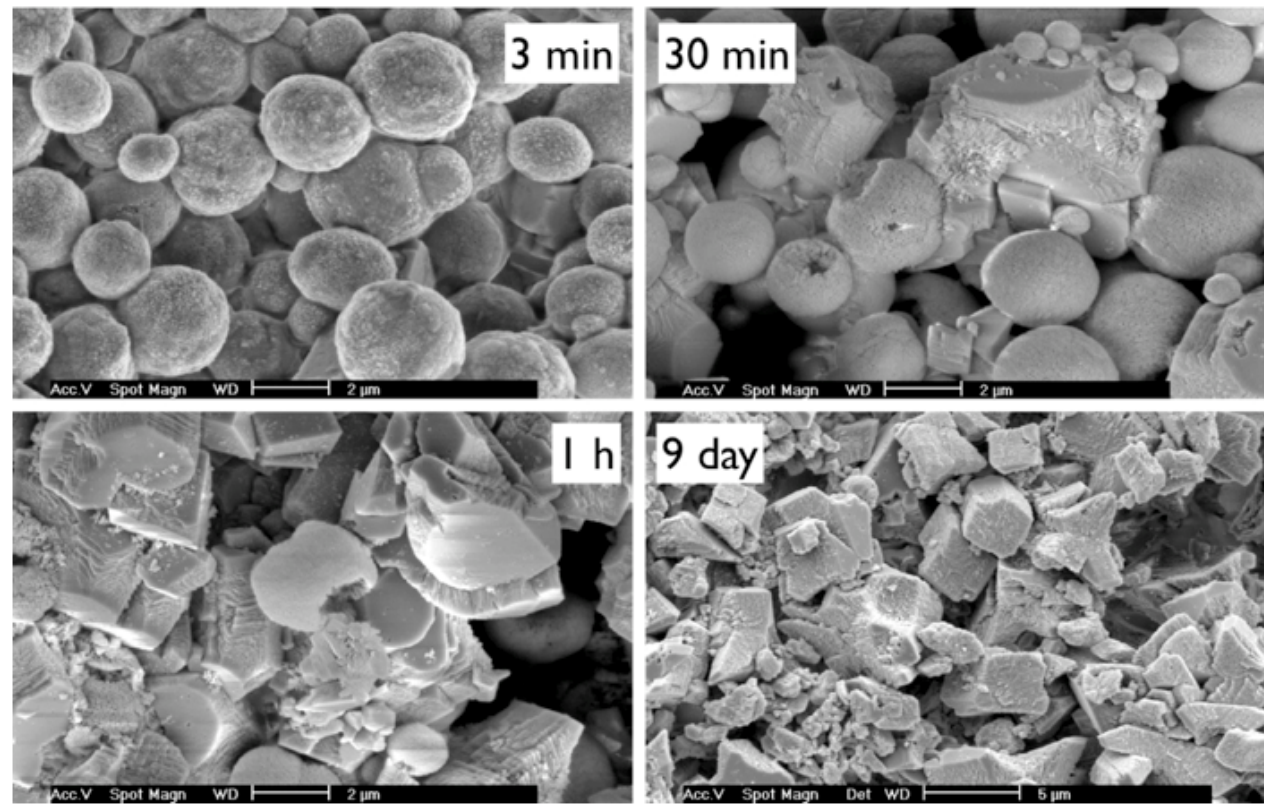

Fig. 4. SEM micrographs showing calcium carbonate crystallization with polyacrylamide. Initially formed vaterite transformed into mesocrystal-like calcite. [Kim, 2004]

Mesocrystal formation (probably through amorphous precursor particles) has been extensively studied and reviewed. [Cölfen and Antonietti, 2005] This non-classical crystallization pathway utilizes the building blocks of nanoparticles to generate superstructures of complex morphologies. Early examples of calcium carbonate mesocrystals utilized silica, gelatin, and polyacrylamide gels. [Dominquez-Bella and GarciaRuiz, 1986; Grassmann et al., 2002, 2003] More elegant and selective method was shown using poly(styrene sulfonate). Poly(styrene sulfonate) adsorbed selectively on highly polar (001) faces of calcite to generate porous mesocrystals with crystallographically well-ordered primary particles. [Wang et al., 2005] When polyacrylamide $(0.50 \%)$ was used as an additive 
in a supersaturated solution of calcium carbonate $(0.10 \mathrm{M})$, rather than as a gel matrix, mesocrystal-like calcite was also obtained. [Kim, 2004] Initially, spherical vaterite was obtained, and it transformed into calcite with time. As shown in Figure 4 (30 min), multiple vaterite particles were in contact with a calcite crystal probably acting as concurrent reservoirs for calcite growth, which appeared to contribute the moesocrystal-like features of calcite at the end. Also, the spherical shape of vaterite suggested that the initial phase could be amorphous calcium carbonate.

As stated in section 2.3, the amorphous calcium carbonate (ACC) is one of the important keys to accomplish the high level of controls observed in biomineralization. Some of the many examples, where simple ACC formation was successful, include those with ethanol, magnesium, surfactant, and phytic acid. [Lee et al., 2005; Loste et al., 2003; Li and Mann, 2002; Xu et al., 2005] When calcium carbonate precipitated in the ethanol solution of calcium chloride via the decomposition of ammonium carbonate to generate carbon dioxide, ACC formed with some included ammonia and carbon dioxide, which could be removed later through heating at $100^{\circ} \mathrm{C}$. [Lee et al., 2005] When magnesium ion was present at high concentrations in the calcium carbonate solutions, ACC formed as a transient phase, and its stability was improved as the amount of magnesium ion increased. [Loste et al., 2003] When ACC nanoparticles were stabilized with a surfactant, its assembly process was manipulated to generate diverse forms of crystalline calcium carbonate. [ $\mathrm{Li}$ and Mann, 2002] ACC formation with phytic acid presented an interesting scenario of making hollow ACC spheres. Anhydrous ACC nanoparticles initially formed, aggregated, and eventually transformed into hydrated ACC leaving only the exterior of the aggregated superstructures. [Xu et al., 2005]

ACC formation and/or stabilization via polymeric additives have been found in a number of publications. Some of the representative examples include those on utilizing polyaspartic acid, poly(propylene imine) dendrimers, and polyacrylate. [Dai et al., 2007; Gower and Odom, 2000; Donners et al., 2000; Jiang et al., 2009] Polyaspartic acid was employed to generate so-called a polymer-induced liquid-precursor (PILP) phase (a highly hydrated ACC), which could assemble and transform into various unusual morphology of calcium carbonate. [Dai et al., 2007; Gower and Odom, 2000] Poly(propylene imine) dendrimers (5th generation) that produced ACC particles were unique in that the kinetics of ACC-to-calcite transformation could be modulated with addition of surfactants, such as octadecylamine (stabilizing ACC) and cetyltrimethylammonium bromide (only calcite observed possibly because of ACC destabilization). [Donners et al., 2000] Polyacrylate, on the other hand, showed a simple example where the ACC formation was regulated in its size and stability by the molecular weight and amount of the polymer; it is interesting that metastable aragonite formed as the major phase when ACC was not stabilized. [Jiang et al., 2009]

ACC formation has been also found under spatial confinement. Well-defined ACC experiments that systematically studied the effects of confinement were performed with polycarbonate track-etch membranes and crossed half-cylinders. [Loste et al., 2004; Stephens et al., 2010] Cylindrical pores (diameters 0.2, 0.8, 3.0, and $10.0 \mu \mathrm{m}$ ) in the membranes were utilized to form confined calcium carbonate under transient ACC forming or non-forming conditions. ACC precursors were necessary as the initial phase to faithfully fill the pores (diameters $\leq 3.0 \mu \mathrm{m}$ ) and eventually form rod-shaped calcite, but $10.0-\mu \mathrm{m}$ pores were too large to give such confinement effects. [Loste et al., 2004] The crossed half-cylinders were employed to probe the effects of spatial restriction on the stability of ACC. (The surface of 
the half-cylinder was self-assembled monolayers of mercaptohexadecanoic acid on Au.) The decreased gap between half-cylinders approaching the contact point demonstrated the kinetic stabilization of ACC due to confinement. [Stephens et al., 2010]

\section{Case studies of the biomineralization of calcium oxalate}

The examples in section 2 exhibited well-defined biominerals of calcium carbonate that were utilized in biological species for the structural and functional reasons. Similar examples of calcium oxalate biominerals could be found in various species. [Lowenstam and Weiner, 1989] However, the focus of this section will be limited to the pathological stones of calcium oxalate. Kidney stones are affecting about $10 \%$ of the populations, and their compositions include calcium phosphate and calcium oxalate. Calcium oxalate has been the focus of the majority of studies because it is the main constituent of the many kidney stones. The pathological biominerals of calcium oxalate differ from the previously discussed calcium carbonate in that their structures are relatively irregular with strong crystal aggregation to form kidney stones.

Calcium oxalate usually forms crystals as hydrates, and calcium oxalate monohydrate (COM) and calcium oxalate dihydrate (COD) are the most common forms. The research on calcium oxalate can be largely categorized into the studies of surface adhesion and growth modulation. In both cases, the atomic force microscopy (AFM) has played crucial roles in measuring adhesion forces at nanonewton scale and visualizing the growth of calcium oxalate at near molecular level.
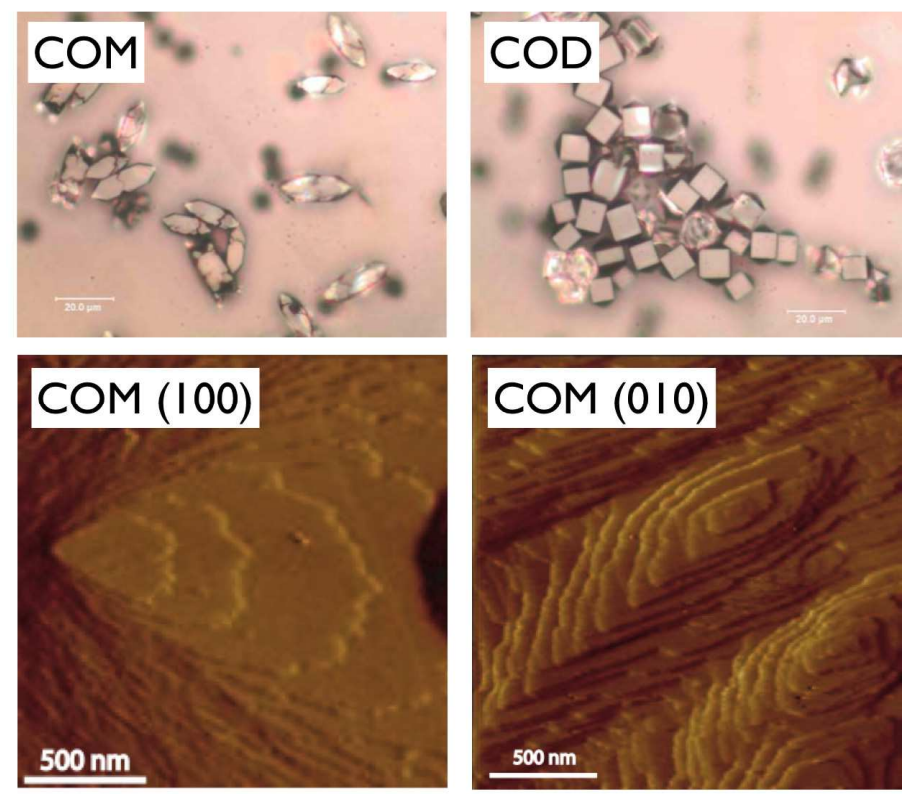

Fig. 5. Examples of COM and COD crystals (top optical microscope images) and the growth hillocks on COM (100) and (010) faces (bottom AFM images). [Kim, 2009] 


\subsection{Adhesion at calcium oxalate surfaces}

The most common kidney stones form as COM aggregates, which makes the study of crystal adhesion extremely important in understanding the disease mechanism. Since the proteins implicated in the COM aggregation contain functional groups, such as carboxylates, amidinums, and alcohols, the specific interactions between the chemical groups and the surfaces of calcium oxalates have been investigated. [Sheng et al., 2003, 2005a, 2005b] Probably the most important finding in the adhesion study is the relative adhesion strength between $\mathrm{COM}$ and $\mathrm{COD}$ surfaces. Generally, $\mathrm{COM}$ showed stronger adhesion to the $\mathrm{Au}: \mathrm{S}\left(\mathrm{CH}_{2}\right)_{10} \mathrm{COO}^{-}$and $\mathrm{Au}: \mathrm{S}\left(\mathrm{CH}_{2}\right)_{2} \mathrm{NHC}_{(}\left(\mathrm{NH}_{2}{ }^{+}\right) \mathrm{NH}_{2}$ groups, which were prepared by reacting appropriate thiols on the gold-coated AFM tips. Especially, COM (100) and COD (101) faces showed the strongest and weakest adhesion, respectively. Since the COM (100) and COD (101) are most exhibited surfaces for the calcium oxalate hydrates, the results of adhesion measurements strongly corroborate the frequent observation of COM aggregate stones and the benign characteristic of COD. [Sheng et al., 2005b] Another interesting finding is the decreased adhesion force in the presence of citrate, a recognized inhibitor of COM formation and aggregation. [Sheng et al., 2005b]

\subsection{Molecular modulation of calcium oxalate growth}

COM growth was studied in detail to understand the role of the growth inhibitors, citrate and osteopontin. [Qiu et al., 2004] Also, synthetic Asp-rich peptides were attempted to mimic the effects of osteopontin. [Wang et al., 2006] In situ AFM was utilized in both studies to observe the effects of the additives on the specific surfaces of COM crystals. Citrate induced dramatic changes in the growth on COM (100) faces, and osteopontin showed strong inhibitory effects on COM (010) faces, clearly demonstrating the specific interactions between the additive molecules and the surfaces of COM crystals. [Qiu et al., 2004] When (DDDS) ${ }_{6} \mathrm{DDD}$ and (DDDG) 6 DDD peptides were present during the growth of COM crystals, the peptide with serine residue showed stronger inhibitory effect than that with glycine spacer. [Wang et al., 2006] The significance of the COM growth studies would increase when combined with the adhesion experiments (section 3.1) because COM crystals in the kidney stones are often found as aggregates rather than single crystals.

Before closing the section of pathological mineralization of calcium oxalate, two loosely related studies on the nucleation of calcium oxalate crystals are briefly reviewed. First, COM formation was promoted in the presence of brushite (or dicalcium phosphate dihydrate, $\mathrm{CaHPO}_{4} \cdot 2 \mathrm{H}_{2} \mathrm{O}$ ). [Tang et al., 2006] Since the calcium oxalate stone formation is often associated with calcium phosphate, the role of the phosphate phase is of great interest to understand the initial stage of the stone formation. [Evan et al., 2003] When a supersaturated but metastable solution of calcium oxalate, which could represent the physiological situation in the urinary space, was observed for more than 2 days, no nucleation of COM was visible. However, when phosphate was present in the system, brushite formed as the initial phase, which in turn induced the COM formation. [Tang et al., 2006] This study suggested the crucial role of heterogeneous nucleation for COM formation. Second, COD formation induced by poly(acrylic acid) was via transformation of amorphous calcium oxalate. [Kim, 2010] When a supersaturated solution of calcium oxalate was prepared with poly(acrylic acid), COD formed instead of COM. [Sheng et al., 2005b] When the crystal formation was observed on self-assembled monolayers $\left(\mathrm{Au}: \mathrm{S}\left(\mathrm{CH}_{2}\right){ }_{10} \mathrm{COO}^{-}\right.$and $\left.\mathrm{Au}: \mathrm{S}\left(\mathrm{CH}_{2}\right)_{11} \mathrm{NH}_{3}{ }^{+}\right)$, amorphous phase was detected. It is unclear at this stage whether the 
amorphous particles aggregate and transform into COD crystals in a similar fashion as the ACC-to-calcite transformation or they simply act as an initial phase that later dissolves to form more stable COD. However, it is interesting that similar behavior was not seen under COM-favorable conditions where the polymeric additive was absent. [Kim, 2010] This study suggested that when COM was prevented through the macromolecular inhibitors, COD could form via amorphous phase to effectively reduce the concentration of calcium oxalate in the originally supersaturated solution.

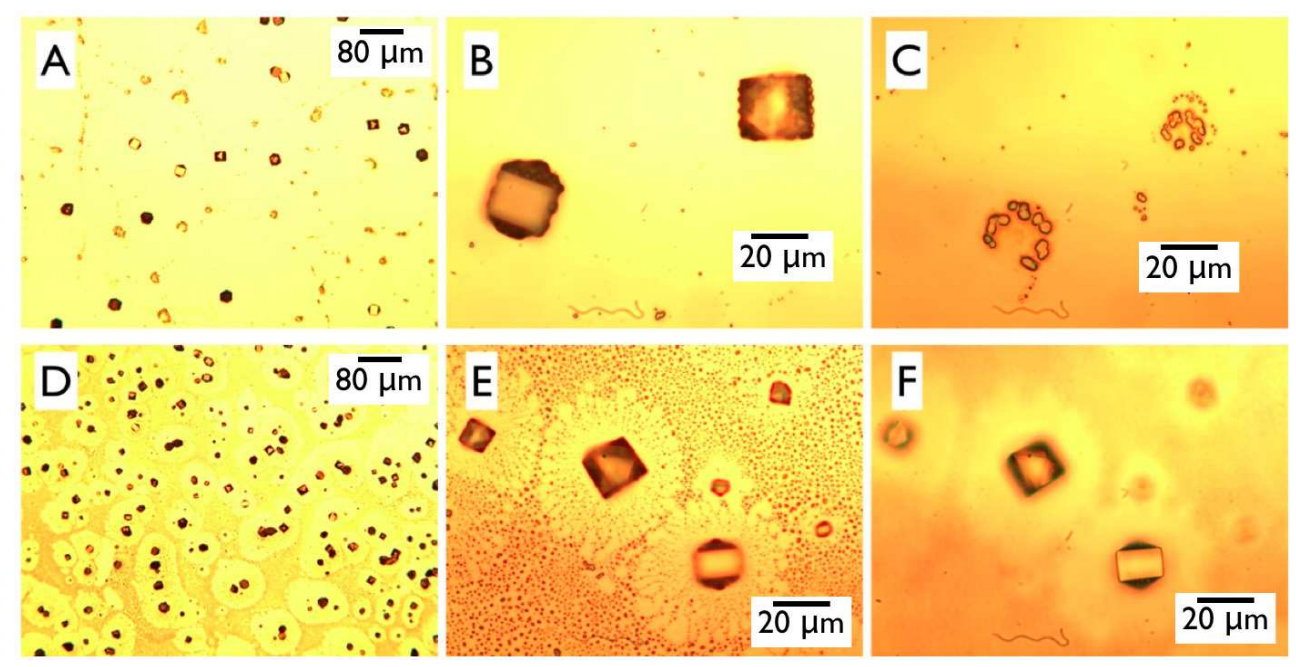

Fig. 6. COD formation on $\mathrm{Au}: \mathrm{S}\left(\mathrm{CH}_{2}\right)_{10} \mathrm{COO}^{-}$: (A) a large area view, (B) COD crystals with amorphous particles attached to them, (C) amorphous particles; COD formation on $\mathrm{Au}: \mathrm{S}\left(\mathrm{CH}_{2}\right)_{11} \mathrm{NH}_{3}{ }^{+}$: (D) a large area view, (E) COD crystals surrounded by amorphous particles, (F) same image as (E) except that the focus was on COD. [Kim, 2010]

\section{Summary}

This chapter has dealt with biomineralization and biomimetic/bioinspired crystallization with special emphasis on macromolecular additives. Among the diverse types of biominerals, calcium carbonate and calcium oxalate have been discussed. Case studies of calcium carbonate biominerals have been focused on the shells of $H$. rufescens and P. fucata. Examples of calcium oxalate biominerals have been limited to the kidney stones. The shells of mollusks and the pathological stones of kidney are contrastingly different as the structures are highly well defined for the former and irregular for the latter. In dealing with the examples, it is clear that organic macromolecules play the central role in regulating the inorganic components.

Several unusual phenomena observed in the biomineralization of mollusk shells include selective formation of metastable aragonite polymorph and normally unstable amorphous calcium carbonate as well as the extraordinary control for the complex morphology. While the intricately controlled microenvironment in vivo is apparently important, the special functions of the biomacromolecules have been attributed to their amino acid compositions 
and secondary structures. Numerous examples exist to mimic the unusual phenomena in vitro, and some representative examples have been introduced. When the successful approaches are extended to other materials, the results of the aforementioned studies would be fully realized as the new paradigm of the crystallization engineering.

Calcium oxalate aggregates in kidney stones are mainly calcium oxalate monohydrate, and the dihydrate form is known as generally benign. This phenomenon is closely related to the strength of surface adhesion that is different between the monohydrate and dihydrate. Also, the molecules known as the inhibitors of stone formation appear to retard both adhesion and growth of the monohydrate. The understanding of the formation and inhibition mechanisms has opened new possibilities for the disease prevention and treatment.

\section{Acknowledgment}

This work was supported by the Korea Research Foundation Grant funded by the Korean Government (KRF-2008-331-D00117) and the Human Resources Development of the Korea Institute of Energy Technology Evaluation and Planning (KETEP) grant funded by the Ministry of Knowledge Economy, Republic of Korea (20104010100610).

\section{References}

Aizenberg J, Lambert G, Addadi L, and Weiner S (1996) Adv. Mater. 8, 222-226.

Aizenberg J, Lambert G, Weiner S, and Addadi L (2002) J. Am. Chem. Soc. 124, 32-39.

Amos FF and Evans JS (2009) Biochemistry 48, 1332-1339.

Amos FF, Destine E, Ponce CB, and Evans JS (2010) Cryst. Growth Des. 10, 4211-4216.

Amos FF, Ponce CB, and Evans JS (2011) Biomacromolecules 12, 1883-1890.

Belcher AM, Wu XH, Christensen RJ, Hansma PK, Stucky GD, and Morse DE (1996) Nature 381, 56-58.

Collino S, Kim IW, and Evans JS (2008) Biochemistry 47, 3745-3755.

Cölfen H and Antonietti M (2005) Angew. Chem. Int. Ed. 44, 5576-5591.

Dai L, Douglas EP, and Gower LB (2008) J. Non-Crystal. Solids 354, 1845-1854.

Dominguez Bella S and Garcia-Ruiz JM (1986) J. Cryst. Growth 79, 236-240.

Donners JJJM, Heywood BR, Meijer EW, Nolte RJM, Roman C, Schenning APHJ, and Sommerdijk NAJM (2000) Chem. Commun. 1937-1938.

Elhadj S, De Yoreo JJ, Hoyer JR, and Dove PM (2006) Proc. Natl. Acad. Sci. USA 103, 1923719242.

Evan AP, Lingeman JE, Coe FL, Parks JH, Bledsoe SB, Shao Y, Sommer AJ, Paterson RF, Kuo RL, and Grynpas M (2003) J. Clin. Invest. 111, 607-616.

Falini G, Albeck S, Weiner S, and Addadi L (1996) Science 271, 67-69.

Fu G, Valiyaveettil S, Wopenka B, and Morse DE (2005a) Biomacromolecules 6, 1289-1298.

Fu G, Qiu SR, Christine AO, Morse DE, and De Yoreo JJ (2005b) Adv. Mater. 17, 2678-2683.

Gotliv B-A, Addadi L, and Weiner S (2003) ChemBioChem 4, 522-529.

Gotliv B-A, Kessler N, Sumerel JL, Morse DE, Tuross N, Addadi L, and Weiner S (2005) ChemBioChem 6, 304-314.

Gower LB and Odom DJ (2000) J. Cryst. Growth 210, 719-734.

Grassmann O, Müller G, and Löbmann P (2002) Chem. Mater. 14, 4530-4535.

Grassmann O, Neder RB, Putnis A, and Löbmann P (2003) Am. Mineral. 88, 647-652.

Hosoda N, Sugawara A, and Kato T (2003) Macromolecules 36, 6449-6452. 
Jiang F, Yang Y, Huang L, Chen X, and Shao Z (2009) J. Appl. Polym. Sci. 114, 3686-3692.

Keene EC, Evans JS, and Estroff LA (2010a) Cryst. Growth Des. 10, 1383-1389.

Keene EC, Evans JS, and Estroff LA (2010b) Cryst. Growth Des. 10, 5169-5175.

Kim IW (2004) Ph.D. thesis, University of Michgan at Ann Arbor.

Kim IW (2009) J. Res. Inst. Frontier Tech. (Soongsil University) 39, 8-13.

Kim IW (2010) J. Res. Inst. Frontier Tech. (Soongsil University) 40, 1-6.

Kim IW, Morse DE, and Evans JS (2004a) Langmuir 20, 11664-11673.

Kim IW, DiMasi E, and Evans JS (2004b) Cryst. Growth Des. 4, 1113-1118.

Kim IW, Robertson RE, and Zand R (2005) Cryst. Growth Des. 5, 513-522.

Kim IW, Collino S, Morse DE, and Evans JS (2006a) Cryst. Growth Des. 6, 1078-1082.

Kim IW, Darragh MR, Orme C, and Evans JS (2006b) Cryst. Growth Des. 6, 5-10.

Kim R, Kim C, Lee S, Kim J, and Kim IW (2009) Cryst. Growth Des. 9, 4584-4587.

Kono M, Hayashi N, and Samata T (2000) Biochem. Biophys. Res. Comm. 269, 213-218.

Lakshminarayanan R, Valiyaveettil S, and Loy GL (2003) Cryst. Growth Des. 3, 953-958.

Lee HS, Ha TH, and Kim K (2005) Mater. Chem. Phys. 93, 376-382.

Li X, Chang W-C, Chao YJ, Wang R, and Chang M (2004) Nano Lett. 4, 613-617.

Li X, Xu Z-H, and Wang R (2006) Nano Lett. 6, 2301-2304.

Liu D, Tian H, Kumar R, and Zhang L (2009) Macromol. Rapid Commun. 30, 1498-1503.

Liu H-L, Liu S-F, Ge Y-J, Liu J, Wang X-Y, Xie L-P, Zhang R-Q, and Wang Z (2007) Biochemistry 46, 844-851.

Loste E, Park RJ, Warren J, and Meldrum FC (2004) Adv. Funct. Mater. 14, 1211-1220.

Loste E, Wilson RM, Seshadri R, and Meldrum FC (2003) J. Cryst. Growth 254, 206-218.

Lowenstam HA and Weiner S (1989) On Biomineralization; Oxford University Press: New York.

Mei L and Mann S (2002) Adv. Funct. Mater. 12, 773-779.

Metzler RA, Evans JS, Killian CE, Zhou D, Churchill TH, Appathurai NP, Coppersmith SN, and Gilbert PUPA (2010) J. Am. Chem. Soc. 132, 6329-6334.

Michenfelder M, Fu G, Lawrence C, Weaver JC, Wustman BA, Taranto L, Evans JS, and Morse DE (2003) Biopolymers 70, 522-533.

Miyamoto H, Miyashita T, Okushima M, Nakano S, Morita T, and Matsushiro A (1996) Proc. Natl. Acad. Sci. USA 93, 9657-9660.

Mount AS, Wheeler AP, Paradkar RP, and Snider D (2004) Science 304, 297-300.

Norizuki M and Samata T (2008) Mar. Biotechnol. 10, 234-241.

Politi Y, Mahamid J, Goldberg H, Weiner S, and Addadi L (2007) CrystEngComm 9, 11711177.

Qiu SR, Wierzbicki A, Orme CA, Cody AM, Hoyer JR, Nancollas GH, Zepeda S, and De Yoreo JJ (2004) Proc. Natl. Acad. Sci. USA 101, 1811-1815.

Raz S, Hamilton PC, Wilt FH, Weiner S, and Addadi L (2003) Adv. Funct. Mater. 13, 480486.

Samata T, Hayashi N, Kono M, Hasegawa K, Horita C, and Akera S (1999) FEBS Letters 462, 225-229.

Schechter A, Glazer L, Cheled S, Mor E, Weil S, Berman A, Bentov S, Aflalo ED, Khalaila I, and Sagi A (2008) Proc. Natl. Acad. Sci. USA 105, 7129-7134.

Shen X, Belcher AM, Hansman PK, Stucky GD, and Morse DE (1997) J. Biol. Chem. 272, 32472-32481.

Sheng X, Ward MD, and Wesson JA (2003) J. Am. Chem. Soc. 125, 2854-2855. 
Sheng X, Jung T, Wesson JA, and Ward MD (2005a) Proc. Natl. Acad. Sci. USA 102, 267-272.

Sheng X, Ward MD, and Wesson JA (2005b) J. Am. Soc. Nephrol. 16, 1904-1908.

Skelton NJ, Kordel J, Akke M, Forsen S, and Chazin WJ (1994) Nat. Struct. Biol. 1, 239-245. [YET TO FIND AND READ]

Smith BL, Schaffer TE, Viani M, Thompson JB, Frederick NA, Kindt J, Belcher A, Stucky GD, Morse DE, and Hansma PK (1999) Nature 399, 761-763.

Stephens CJ, Ladden SF, Meldrum FC, and Christenson HK (2010) Adv. Funct. Mater. 20, 2108-2115.

Suzuki M, Saruwatari K, Kogure T, Yamamoto Y, Nishimura T, Kato T, and Nagasawa H (2009) Science 325, 1388-1390.

Takakura D, Norizuki M, Ishikawa F, and Samata T (2008) Mar. Biotechnol. 10, 290-296.

Takeuchi T and Endo K (2006) Mar. Biotechnol. 8, 52-61.

Tang R, Nancollas GH, Giocondi JL, and Orme CA (2006) Kidney Int. 70, 71-78.

Wang L, Qiu SR, Zachowicz W, Guan X, De Yoreo JJ, Nancollas GH, and Hoyer JR (2006) Langmuir 22, 7279-7285.

Wang TX, Cölfen H, and Antonietti M (2005) J. Am. Chem. Soc. 127, 3246-3247.

Weiner S and Addadi L (1997) J. Mater. Chem. 7, 689-702.

Weiss IM, Tuross N, Addadi L, and Weiner S (2002) J Exp Zool 293, 478-491.

Wustman BA, Weaver JC, Morse DE, and Evans JS (2003a) Connect. Tissue Res. 44, 10-15.

Wustman BA, Weaver JC, Morse DE, and Evans JS (2003b) Langmuir 19, 9373-9381.

Wustman BA, Morse DE, and Evans JS (2004) Biopolymers 74, 363-376.

Xu A-W, Yu Qiu, Dong W-F, Antonietti M, and Cölfen H (2005) Adv. Mater. 17, 2217-2221.

Zhang B, Wustman BA, Morse D, and Evans JS (2002) Biopolymers 63, 358-369. 


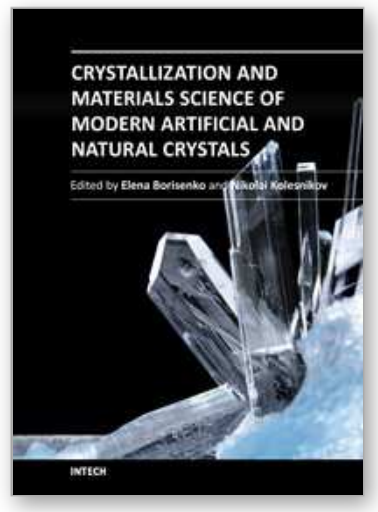

\section{Crystallization and Materials Science of Modern Artificial and Natural Crystals}

Edited by Dr. Elena Borisenko

ISBN 978-953-307-608-9

Hard cover, 328 pages

Publisher InTech

Published online 20, January, 2012

Published in print edition January, 2012

Crystal growth is an important process, which forms the basis for a wide variety of natural phenomena and engineering developments. This book provides a unique opportunity for a reader to gain knowledge about various aspects of crystal growth from advanced inorganic materials to inorganic/organic composites, it unravels some problems of molecular crystallizations and shows advances in growth of pharmaceutical crystals, it tells about biomineralization of mollusks and cryoprotection of living cells, it gives a chance to learn about statistics of chiral asymmetry in crystal structure.

\section{How to reference}

In order to correctly reference this scholarly work, feel free to copy and paste the following:

II Won Kim (2012). Biomimetic and Bioinspired Crystallization with Macromolecular Additives, Crystallization and Materials Science of Modern Artificial and Natural Crystals, Dr. Elena Borisenko (Ed.), ISBN: 978-953-307608-9, InTech, Available from: http://www.intechopen.com/books/crystallization-and-materials-science-ofmodern-artificial-and-natural-crystals/biomimetic-and-bioinspired-crystallization-with-polymeric-additives

\section{INTECH}

open science | open minds

\section{InTech Europe}

University Campus STeP Ri

Slavka Krautzeka 83/A

51000 Rijeka, Croatia

Phone: +385 (51) 770447

Fax: +385 (51) 686166

www.intechopen.com

\section{InTech China}

Unit 405, Office Block, Hotel Equatorial Shanghai

No.65, Yan An Road (West), Shanghai, 200040, China

中国上海市延安西路65号上海国际贵都大饭店办公楼 405 单元

Phone: +86-21-62489820

Fax: +86-21-62489821 
(C) 2012 The Author(s). Licensee IntechOpen. This is an open access article distributed under the terms of the Creative Commons Attribution 3.0 License, which permits unrestricted use, distribution, and reproduction in any medium, provided the original work is properly cited. 